\title{
On the Exploration of the Tri Hita Karana Belief as Balinese Local Wisdom in Tangis Pertiwi Song Lyric
}

\author{
Komang Darmayuda ${ }^{1}$, I Made Netra ${ }^{2}$ \\ Arts Study Program \\ Institute of Arts Indonesia \\ Denpasar \\ komangdarmayuda2804@gmail.com \\ Faculty of Arts -Udayana University \\ Denpasar
}

\begin{abstract}
A song, one of the literary works and arts, is full of the contents of the values of the local wisdom of the community, because its creation is usually based on factual phenomena that are happening in the community. This article aims to see the implementation of Tri Hita Karana belief as the local wisdom of Balinese people in Balinese songs entitled Tangis Pertiwi. This song was comprehensively observed and recorded to be analyzed by qualitative methods with a descriptive approach. The results of data analysis show that the song Tangis Pertiwi has a thematic structure, namely harmony supported by schematic structures that are systematically arranged in song verse, such as the harmonious relationship between humans and nature implied in the first verse, between humans and humans in the second verse, and humans with God Almighty in the third verse. Viewed from the dimensions of cultural meaning, the song Tangis Pertiwi contains moral values in the form of advice and suggestion to always follow the Tri Hita Karana belief, and the norm of apology if something happens outside the belief; the Balinese character is harmonious, humble, alert, forgiving; the symbolic meanings contained in this song are beautiful, safe, sharing, guarding; finally the moral message is literal-indirectly delivered. Whereas in Bali there were many actions that were no longer carried out to enforce Bali, including disobeying Tri Hita Karana belief. Therefore, it is time for Balinese people to apologize to God the Almighty and promise not to do things outside the Tri Hita Karana belief.
\end{abstract}

\section{Index Terms - exploration, Tri Hita Karana, Tangis Pertiwi, harmonious, Balinese}

\section{INTRODUCTION}

A literary work and artwork are full of contents of certain norms, values and ideologies. One of the artworks that is still in great demand is song. It is actually one form of literature and artwork that is given sound effects or music. In other words, it can be said that it is a form of art that resembles musical poetry characterized by a unique diction and poetic diction composed with symmetrical sounds and usually gives an impact to the reader and audience.
Therefore, it is usually written or created to uncover social and cultural phenomena in society that are equipped with music that also gives or reinforces the meaning that is expected to have an impact on society.

The song Tangis Pertiwi by Komang Darmayuda is one of the Balinese songs specifically created to uncover the sociocultural phenomena of the Balinese people. This song also gives advice to the younger generation so that they are able to understand the socio-cultural phenomenon and in the end they are able to maintain and preserve the belief and cultural values embodied in it. On their shoulders the land of Bali will be entrusted, on their shoulders is this cultural value preserved so that it remains steady and lasts forever. 
In particular, this article tries to describe both thematic and schematic structures of the song as well as the dimensions of the Balinese character in their daily life outlined in the song, meanings and values in the Tri Hita Karana belief in certain ways.

\section{MethoD}

The method used in this article refers to three things, namely the method of collecting data, the method of analyzing data, and the method of presenting the results of data analysis. Data were collected by observation method with note taking technique. The song Tangis Pertiwi was comprehensively observed and the song was recorded and transcribed. Then, the data was coded accordingly, and freely translated. Data were analyzed by qualitative method with a descriptive approach. The aspects that were qualitatively described were the thematic structure and schematic structure of the song lyric based on the theory of discourse structure from Van Dijk and the dimension of cultural meanings in the song lyric Tangis Pertiwi. The results of data analysis were informally presented using elaborative paraphrase descriptions (Sudaryanto)

\section{Discussion}

Before having discussed further, the following is the song lyric of Tangis Pertiwi

Akeh tarune katebang jatma corah

Akeh tanah Baline sampun kaadol

Bali nenten asri, Bali nenten aman

Akeh pratimane ical kapaling

Krama Baline masiat ajak nyama

Magarang tapal bates desa pakraman

Pertiwine leteh, leteh antuk getih

Getih sane ulian kacorahan

Tangis pertiwi nyuryaning jagat Bali skadi mangkin

Sami lali pawarah leluhure sane nguni

Duh Sang Hyang Widi ampurayang tityang sareng sami

Nenten kukuh ngemargiang Tri Hita Karana

\section{A. Text Structure}

In general, it can be said that the text structure of the song lyric is in the forms of thematic and schematic structures. It means that the entire theme of the song lyric is systematically and structurally supported by the meaning of each verse, as stated by Van Dijk (1994). In this case the thematic message built in this song is harmony. Harmony can occur in the relationship between humans and nature, humans and humans, and humans and God Almighty. Then the theme of this harmony is structured in each verse which is a schematic message in this song. In the first verse there is a message of harmony between humans and nature. See the following verse (Data 1-1)

Akeh tarune katebang jatma corah

Akeh tanah Baline sampun kaadol

Bali nenten asri, Bali nenten aman

\section{Akeh pratimane ical kapaling}

Many trees had been wildly cut down by bad people

Many of Bali's lands had been sold

Bali is not beautiful, Bali is not safe

Many sacred objects were lost and stolen by people

Data (1-1) shows that there are phenomena that afflict Balinese people which can be said to damage the natural conditions of Bali. The phenomena are explicitly shown in the first two lines of data (1-1), i.e. many trees were cut wildly down, a lot of land had been sold at will, and sacred objects in the temple had been stolen. This makes Bali not beautiful because many trees are cut down and Bali is not safe because of many cases of stealing of sacred objects in the temples in Bali. However, this implies that if we want to carry out the teachings of Tri Hita Karana belief properly and correctly, there should be no actions which are detrimental to Bali's nature, so the thing that really wants to be conveyed is how human relations with nature remain steady and sustainable and harmonious.

In the second verse there is a message of harmony between humans and humans. See the following verse (Data 1-2)

Krama Baline masiat ajak nyama

Magarang tapal bates desa pakraman

Pertiwine leteh, leteh antuk getih

Getih sane ulian kacorahan

Balinese people fight with each other

Fight over the village border area

The land becomes tainted with blood

Blood of dishonesty

Data (1-2) shows that there are phenomena regarding Balinese people attitude who are being in conflict. It is because of fighting with each other to capture the village boundary. This fight may result in the land becomes tainted with blood, specifically it is the so-called the blood of dishonesty. However, this implies that if we want to carry out the teachings of Tri Hita Karana belief properly and correctly, then there should not be conflict between people which causes the fading and collapse of human unity in safeguarding the security Bali and promoting Bali, as well. So, the thing that really wants to be conveyed is how human relations with humans remain steady and sustainable and harmonious.

In the last verse there is a message of harmony between humans and God Almighty. See the following verse (Data 13)

Tangis pertiwi nyuryaning jagat Bali skadi mangkin

Sami lali pawarah leluhure sane nguni

Duh Sang Hyang Widi ampurayang tityang sareng sami

Nenten kukuh ngemargiang Tri Hita Karana

Tangis Pertiwi witnesses Bali today's condition

Everyone forgets ancestor's advice

Oh, God Almighty, please forgive us

Not firmly carrying out the teachings of Tri Hita Karana belief 
Data (1-3) shows that there is a phenomenon that says the land cries and witnesses Bali today's condition shown in the first two verses previously. They even, forget the ancestor's advice. At the end, they cannot be able to implement the teaching of Tri Hita Karana belief. Therefore, Finally, an extraordinary moral message is expressed, namely that if nature has been exploited in such a way, humans do not have harmonious relationship, then certainly there will be disharmony which is certainly contrary to the teachings of Tri Hita Karana belief. Therefore, at the last stanza, how the land of Bali is presented, the nature of Bali crying is made by human behavior. Therefore, it is fitting that when realized from this impact, the Balinese always apologize for their negligence in guarding the land of Bali to God the Almighty.

\section{B. Dimensions for Determining Meaning in Tangis Pertiwi Song Lyric}

To support the thematic structure, that is the theme of Tangis Pertiwi song lyric, namely harmony, then four dimensions to determine cultural meaning are explained and discussed comprehensively. The four dimensions are (1) the situational-behavioral dimension, (2) the linguistic-extra linguistic dimension, (3) the intraorganistic-extraorganistic dimension, and (4) the general-particular dimension

\section{a) Situational-Behavioral Dimension}

The first dimension is situational-behavioral dimension. It is used to determine the meaning in terms of value contained in Tangis Pertiwi song lyrics. It refers to the psychical behavior that leads to the values of human life so that local wisdom can be understood and identified well. The values of local wisdom contained in the lyrics of the Tangis Pertiwi song lyric are: prohibitions as well as solicitation, in which people are not allowed to down trees carelessly, sell the land of Bali at will, let thieves run rampant in the holy place, fight with fellow of Balinese people.

To avoid the occurrence of clearing, selling Bali land, theft of sacred objects, and the intended meaning, it is appealed to human beings who live on this earth to always follow and carry out and obey the teachings of Tri Hita Karana belief. However, if all these phenomena have occurred, then as ordinary human beings and creatures of God, we are expected to always apologize and commit to avoid them so that they will not happen anymore

In addition to the prohibition value, the other value found in the song lyrics of Tangis Pertiwi is an invitation to always obey and carry out the teachings of Tri Hita Karana belief, so that harmony between humans and nature and environment, human beings with human, and humans with the Almighty God are maintained

\section{b) Linguistic-Extra Linguistic Dimension}

The second dimension is the linguistic-extra-linguistic dimension which is a dimension for determining the meaning that refers to the linguistic symbols that exist in the song.
The lyrics of the song Tangis Pertiwi contain several meaningful symbols. This means that the theme of harmony is supported by symbolic meaning in the song that is connected with the context of the situation, so that local wisdom can be understood. The symbols found are as follows:

a. The "tree" found in the first line of the first stanza symbolizes the fertility and well-being. Trees that are well maintained by humans are believed to provide greenery and coolness of the natural atmosphere and in end the end results in natural fertility and harmony

b. Tanah Bali "Land of Bali" found in the second line of the first stanza symbolizes an environment where culture is defined as a result of the feeling and will of human life and development. Here on this land of Bali, human being is able to carry out his ideas and ideas to produce cultural reality in the form of artifacts and cultural activities, so as to create balance and harmony.

c. Bali "Bali island" is found in the third line of the first stanza symbolizes the island of a thousand islands and the island of the Gods where beauty and harmony are here based on the balance of life based on the well-known culture

d. Pratima "sacred object" found in the fourth line of the first stanza symbolizes God. It is considered a tool to worship to God. Pratima or often called a statue is often sacred by the Balinese so that it becomes the way to God

e. Karma Bali "Balinese People" found in the first line of the second stanza symbolizes the order in Balinese society which is always fostered and maintained in a system called Balinese community. There is a uniqueness in how Balinese community carries out kinship on a physical and mental basis so that it creates balance and harmony

f. Tapal bates "village boundary" found in the second line of the second stanza symbolizes the balance of nature because with the boundary, all ownership and boundaries of the village area are clearly described so as to provide balance and harmony

g. Pertiwi "land" found in the third line of the second stanza symbolizes the place where human beings live up to their obligations of carrying out God's commands and avoiding Her prohibitions

h. Getih "blood" found in the fourth line of the second stanza symbolizes the spirit in life so as to provide enthusiasm in life to achieve balance and harmony

i. surya "sun" found in the first line of the third stanza symbolizes the source of energy and the source of life that has many roles that are very important for life so as to create fertility and prosperity in life and in the end create balance and harmony

j. Leluhur "ancestors" found in the second line of the third stanza symbolizes a strong bond of brotherhood and kinship which is always maintained as part of the life cycle in Bali, creating balance and harmony.

k. Sang Hyang Widi "God Almighty" found in the third line of the third stanza symbolizes the greatness and existence of spiritual and supernatural powers that provide happiness to mankind without pauses and cannot be 
distinguished between dreams and reality. God is considered the cause of beauty, the cause of all (the creator) the cause of all that can be witnessed.

1. Tri Hita Karana "Harmony" found in the fourth line of the third stanza symbolizes the cause of the creation of happiness, balance and harmony between humans and nature, humans and humans, and humans and the Supreme God

\section{c) Intraorganistic-Extra Organistic Dimension}

This third dimension is the dimension for determining meaning based on the characters in the text. This means that individual characters and social groups remain highlighted in the text so that local competitiveness can be sustained by the individual character. In the lyrics of the song Tangis Pertiwi, the characters displayed and found are as follows

(1-1) Akeh tarune katebang jatma corah

\section{Akeh tanah Baline sampun kaadol}

Bali nenten asri,Bali nenten aman

Akeh pratimane ical kapaling

Many trees had been wildly cut down by bad people

Many of Bali's lands had been sold

Bali is not beautiful, Bali is not safe

Many sacred objects were lost and stolen by people

The data (1-1) above shows that the Balinese people show their deep inequality because of irresponsible human activities that destroy nature. As a result, the Balinese human characters are upset and sorry for this phenomenon, for the purpose of recovering the invulnerability and anticipating this does not happen anymore, so Balinese people are more expressive in expressing this phenomenon loudly and explicitly.

(1-2) Krama Baline masiat ajak nyama Magarang tapal bates desa pakraman

Pertiwine leteh, leteh antuk getih

Getih sane ulian kacorahan

Balinese people fight with each other

Fight over the village border area

The land becomes tainted with blood

Blood of dishonesty

The data (1-2) above shows that Balinese people are very disappointed with the attitude and behavior of irresponsible people who fight between them with each other's roots so that this causes Balinese to show their expressiveness because of their disappointment

(1-3)Tangis pertiwi nyuryaning jagat Bali skadi mangkin Sami lali pawarah leluhure sane nguni

Duh Sang Hyang Widi ampurayang tityang sareng sami

Nenten kukuh ngemargiang Tri Hita Karana

Tangis Pertiwi witnesses Bali today's condition

Everyone forgets ancestor's advice

Oh, God Almighty, please forgive us

Not firmly carrying out the teachings of Tri Hita Karana belief

The data (1-3) above shows that the Balinese people are so aware that Bali's nature can be damaged by irresponsible people, aware of the importance of managing the balance of nature and humans so that if humans are found stronger, then nature will be increasingly preserved for balance and harmony. Therefore, the Balinese character is apologizing if a problem has been overwritten.

\section{d) General-Particular Dimension}

This dimension is a dimension that refers to how to convey intent. In this case, the way Balinese express and use their local wisdom can be mapped whether in a direct, indirect and literal way it is not literal or its combination. In the land of Bali, there have been many actions which have not taken place in Bali, ignoring the teachings of Tri Hita Karana belief because not a few people do think about the harmonious relationship between humans and nature, humans and humans, and God Almighty. This is proven by:

a. Trees are forcibly cut down without permission by irresponsible people who answer for personal silence

b. The land of Bali has been sold and fallen to investors who do not expect conservation so that less land is left for greening and vice versa is very volatile land conversion takes place and ultimately disasters such as natural disasters occur.

c. Sacred objects that are stolen in the temple or sacred devotions sacred by Hindus are stolen by irresponsible people so that they can destroy the human hub order with the all-powerful God

d. People who fight with each other, fight to defend and capture the village boundary that causes the land of Bali to become a land that is not sacred anymore because of the actions of an irresponsible group of humans

\section{Conclusion}

The results of the discussion can be concluded as follows:

a. Tangis Pertiwi song lyric has a thematic structure, namely harmony supported by schematic structures that are systematically arranged in song stanzas, such as the harmonious relationship between humans and nature implied in the first stanza, between humans and humans in the second stanza, and humans with God Almighty in the third verse.

b. Seen from the dimensions of cultural meaning, the Tangis Pertiwi song contains moral values in the form of advice and an appeal to always follow and obey the Tri Hita Karana belief, and norms of an apology if something happens beyond the belief; the Balinese character is harmonious, humble, alert, forgiving; the symbolic meanings contained in this song lyric are beautiful, safe, sharing, guarding; finally the moral message is delivered indirectly and literally.

\section{REFERENCES}

[1] 